\title{
Rechtsstatelijke waarborging van buitengerechtelijke conflictoplossing - onderzoeksrapport Montaigne Centrum
}

\author{
Marc Simon Thomas
}

Hoe verhouden huidige vormen van buitengerechtelijke geschiloplossing zich tot de kernwaarden van de rechtsstaat? Dat is wat het Wetenschappelijk Onderzoeken Documentatiecentrum (WODC) van het Nederlandse ministerie van Justitie en Veiligheid een paar jaar geleden wilde weten. De achtergrond hiervan ligt in een eerder initiatief van de directie Rechtsbestel van dat ministerie om uitgangspunten te formuleren voor een strategische agenda, waarbij het vooral gaat om een hedendaagse invulling van rechtsstatelijke waarden, op basis van behoeften van burgers en maatschappelijke ontwikkelingen en trends. Eén zo'n trend is de gestage opmars sinds enkele decennia van buitengerechtelijke, ook wel 'alternatieve' geschiloplossing (ADR) binnen het Nederlandse rechtsbestel. De vraag hoe dergelijke vormen van ADR zich verhouden tot rechtsstatelijke waarborgen, aangevuld met de vraag welke ijkpunten zouden kunnen worden geformuleerd om deze waarborgen te versterken, vormde het uitgangspunt van een onderzoek dat in opdracht van het WODC in 2017 is afgerond door het Montaigne Centrum voor Rechtsstaat en Rechtsontwikkeling van de Universiteit Utrecht. Het onderzoeksrapport is begin dit jaar in boekvorm verschenen bij Boom Juridische uitgevers. $^{1}$

De oudste vorm van buitengerechtelijke geschiloplossing die Nederland kent, is dat van arbitrage. Van recentere datum zijn de beide andere varianten, bindend advies en mediation. Dit drietal vormt een aanvulling op overheidsrechtspraak en door het toenemende aanbod daarvan op de markt van geschiloplossing komt steeds vaker en indringender de vraag op of er niet meer behoefte is aan waarborgen voor de gebruikers van dit private aanbod, rechtsstatelijke waarborgen die ook ten grondslag liggen aan overheidsrechtspraak. Tegelijkertijd is er het besef dat deze alternatieven hun toegevoegde waarde voor diezelfde gebruikers vooral ontlenen aan het feit dat zij informeler en daarmee ook vaak sneller zijn en meer maatwerk bieden. Er is dan ook duidelijk een spanning tussen de klassieke rechtsstatelijke waarborgen die overheidsrechtspraak biedt en de effectiviteit van de alternatieven. Het zoeken van een benadering die het evenwicht tussen beide weet te vinden staat centraal in het boek.

De eerste stap in het onderzoek dat ten grondslag ligt aan het boek Rechtstatelijke waarborging van buitengerechtelijke geschiloplossing was om op basis van onderzoek

1 E. Bauw, C.C. de Kluiver, M.A. Simon Thomas \& W. van der Woude, Rechtsstatelijke waarborging van buitengerechtelijke geschiloplossing, Den Haag: Boom Juridisch uitgeverij 2018. 
van literatuur en jurisprudentie een overzicht te geven welke rechtsstatelijke waarborgen kunnen worden onderscheiden. Maar misschien nog wel belangrijker was om te identificeren welke relevantie deze waarborgen toekomt in de specifieke context van ADR. In het boek komen legaliteit (de mate waarin de derde partij die betrokken is bij de geschiloplossing gebonden is aan het recht), toegang tot het recht, de onafhankelijkheid van de geschilbeslechter of een mediator, de onpartijdigheid van de derde en ten slotte een aantal overige eisen die aan de behandeling van de zaak gesteld kunnen worden (zoals openbaarheid, motivering, redelijke termijn en equality of arms) aan de orde. Vervolgens zijn deze inzichten in de vorm van expert meetings en focusgroepen voorgelegd aan een forum van vertegenwoordigers van wetenschap en praktijk om zo, middels methodologische triangulatie, tot een validatie van de resultaten en verdere inzichten te komen.

Tegelijk is het veld van alternatieve geschiloplossing, bestaande uit arbitrage, bindend advies en mediation in Nederland beschreven, waarbij specifiek is gekeken hoe de verschillende waarborgen hier zijn geborgd. Ten aanzien van bindend advies en mediation is dit vervolgens uitgediept in drie case studies naar: 1) het Klachteninstituut financiële dienstverlening (Kifid), 2) scheidingsmediation en 3) alternatieve geschiloplossing bij de overheid. De uitkomsten van dit deel van het onderzoek laten zien dat het algehele beeld waar het gaat om het voldoen aan rechtsstatelijke waarborgen door aanbieders van ADR bepaald niet negatief is. Waar sprake is van voor ADR relevante waarborgen geldt dat deze in de meeste gevallen bij wet (vooral arbitrage), reglement (bijvoorbeeld het regelement dat geldt voor MfN-registermediators) of anderszins zijn verzekerd. Op verschillende niveaus is daarnaast al sprake van de nodige overheidsbemoeienis met de belangrijkste varianten van ADR, zoals het Kifid of de geschillencommissies. De geconstateerde positieve stand van zaken lijkt dan ook geen reden te bieden voor ingrijpende wijziging van het huidige stelsel. Het uitgangspunt, zo blijkt uit het boek, zou dan ook moeten zijn dat met de formalisering van ADR teneinde meer partijen meer waarborgen te bieden terughoudendheid geboden is. Verdere formalisering zou immers ten koste kunnen gaan van de aantrekkelijkheid en kracht van ADR. Dit is een eerste belangrijke conclusie die in het boek wordt getrokken.

$\mathrm{Nu}$ er geen aanleiding is tot zorg op korte termijn, ligt ingrijpende wijziging niet in de rede, zo stellen de auteurs. Voor de toekomst is echter van belang dat de ontwikkelingen nauwgezet worden gevolgd en te bezien of ingrijpen alsnog geraden is. Voor de vraag wanneer dat laatste het geval is, kunnen geen eenduidige ijkpunten worden gegeven. Daarvoor zijn de drie vormen van ADR en de varianten daarbinnen te divers. Het WODC vroeg in zijn aanbesteding wel om dergelijke ijkpunten, maar het onderzoek wees al snel uit dat die niet gegeven zouden kunnen worden. De onderzoekers hebben daarom gezocht naar een beoordelingskader dat recht doet aan die diversiteit en dat tegelijk voldoende aanknopingspunten biedt om het stelsel als een geheel mee te benaderen. Geïnspireerd door Alex Brenninkmeijer - die nauw betrokken was bij de opzet van het onderzoek - suggereren de auteurs om twee paradigma's tegenover elkaar te plaatsen. ${ }^{2}$

2 A. Brenninkmeijer, Mediation, in: A. Brenninkmeijer, D. Bonenkamp, K. van Oyen \& H. Prein, Handboek Mediation, Den Haag, Sdu uitgevers 2017, p. 47-49. 
Het eerste is het paradigma van de waarborgen, dat de vormgeving van het stelsel van overheidsrechtspraak in hoge mate heeft bepaald en dat wordt gedomineerd door wetten, regels en formalisme. Dit heeft zowel bijgedragen aan de betrouwbaarheid van het stelsel en het vertrouwen van burgers in dat stelsel als aan de gebreken van het stelsel, zoals relatieve traagheid en kostbaarheid van procedures en een gebrek aan oplossend vermogen. Het tweede paradigma is dat van de autonomie en zelfbeschikking. Hierin staat de keuzevrijheid en zelfbeschikking van partijen centraal om zelf de vorm en inhoud te bepalen van de oplossing van hun geschil. Het is geen vanzelfsprekendheid dat dit een overheidsaangelegenheid is die regelgeving of toezicht vereist. Hier geldt dat evenals het partijen in beginsel vrijstaat om de overeenkomsten aan te gaan die zij verkiezen (contractsvrijheid), zij ook de beslechting of oplossing van hun geschil zelf kunnen vormgeven. De beide paradigma's vormen als Idealtypen de uiteinden van een schaal waarop de verschillende vormen en varianten van ADR kunnen worden geplaatst.

Uit het onderzoek kunnen indicatoren (ofwel, het alternatieve beoordelingskader dat in het boek is gevonden voor de gevraagde, maar niet te leveren ijkpunten) worden afgeleid aan de hand waarvan kan worden beargumenteerd welk paradigma ten aanzien van welke modaliteit van ADR dominant is of zou behoren te zijn. Daarbij staan het perspectief van de ADR-afnemer, de gebruiker, en de verwachting die hij redelijkerwijs mag hebben met betrekking tot de rechtsstatelijke waarborgen centraal. Deze verwachtingen zijn meer gerechtvaardigd naarmate: 1) de (ADR-stimulerende) bemoeienis van overheid groter is; 2) de feitelijke keuzevrijheid van de ADR-afnemer ten aanzien van het aangaan van een ADR-traject kleiner is; 3) de ADR-aanbieder kan worden aangemerkt als een meer professionele aanbieder en/of 4) de ADR-aanbieder optreedt als geschilbeslechter in plaats van als procesbegeleider. Daarmee kunnen deze factoren worden gezien als indicatoren voor overheidsregulering van of overheidstoezicht op ADR. Dit overigens nog los van de vraag hoe die regulering of dat toezicht er dan uit zou kunnen/ moeten zien.

Voor die overheidsbemoeienis worden vervolgens vier handelingsopties beschreven, waarvan er twee al in het huidige stelsel een plaats hebben: zelfregulering door de branche en (marginaal) toezicht door de rechter op de 'producten' van ADR (arbitrale vonnissen en vaststellingsovereenkomsten in het geval van bindend advies en mediation). Twee andere, (veel) verdergaande opties zijn van meer theoretische aard: bestuurlijk toezicht vanuit de centrale overheid of vanuit een afzonderlijke decentrale overheid. Desondanks zien de auteurs deze al wel toegepast in specifieke sectoren in het juridische domein, zoals de advocatuur en notariaat en daarom verdienen zij - hoewel thans nog niet aan de orde - dan ook een beschrijving in het concluderende hoofdstuk van het boek. 